\title{
Genotypic Diversity, Antimicrobial Resistance and Screening of Vibrio cholerae Molecular Virulence Markers in Vibrio alginolyticus Strains Recovered from a Tunisian Ruditapes decussatus Hatchery
}

\author{
BADREDDINE MECHRI ${ }^{1,2 *}$, AMEL MEDHIOUB ${ }^{2}$, MOHAMED NEJIB MEDHIOUB $^{2}$ and MAHJOUB AOUNI \\ ${ }^{1}$ Laboratoire des Maladies Transmissibles et Substances Biologiquement Actives, Université de Monastir, \\ Faculté de Pharmacie, rue Avicenne 5000 Monastir, Tunisie \\ ${ }^{2}$ Laboratoire d'Aquaculture - Institut National des Sciences et Technologies de la Mer, \\ Route de Khniss 5000 Monastir - B.P. 59, Tunisie
}

Submitted 6 December 2012, revised 2 June 2013, accepted 15 July 2013

Abstract

\begin{abstract}
In this study, a total of 54 Vibrio alginolyticus strains were analyzed. The isolates were recovered from different compartments of the Ruditapes decussatus hatchery in the National Institute of Marine Sciences and Technologies, Monastir, Tunisia. All isolates were biochemically identified (API 20E and API ZYM strips), characterized by amplification of the Hsp-40 gene polymerase chain reaction (PCR) and analyzed by enterobacterial repetitive intergenic consensus (ERIC)-based genotyping to evaluate genetic relationship between the isolated strains. We also looked for the presence of ten $V$. cholera virulence genes (toxRS, toxR, toxT, toxS, tcpP, tcpA, ace, vpi, zot and $\operatorname{ctxA}$ ) in the genomes of Vibrio isolates. The antibiotics susceptibility, exoenzymes production and in vitro cytotoxic activitiy against HeLa cell line were also carried out for all tested bacteria. Most of V.alginolyticus isolates showed significant antimicrobial resistance rates to at least ten antibacterial agents. For most isolates, the minimum inhibitory concentration (MIC) data showed that tetracyclin and streptomycin were the most effective antibiotics. Construction of the phylogenetic dendogram showed that studied isolates were in general genetically heterogeneous; however some Vibrio strains were present in different structures of the $R$. decussatus hatchery. The V. cholerae virulence genes investigation showed a wild distribution of toxS (49/54), toxR (45/54) and toxT (22/54) genes among V. alginolyticus strains isolated from the $R$. decussatus rearing system. Cytotoxic effects of several Vibrio extracellular products (28/54) were also observed on HeLa cells.
\end{abstract}

Ke y w o rd s: Vibrio alginolyticus, Ruditapes decussatus, hatchery, ERIC-PCR, virulence genes

\section{Introduction}

The grooved carpet shell, Ruditapes decussatus (Linnaeus, 1758) belonging to the Venerideae family is common in estuaries and lagoons of most of the Mediterranean (Parache, 1982; Lubert, 1984). In Tunisia, it is present on almost all the coast, especially in the Gulf of Gabes (Medhioub, 1983) and represents the most socioeconomically important shellfish in terms of both employment and value (Hamida et al., 2004). In the last decade, the $R$. decussatus clam has been produced in the experimental hatchery of the National Institute of Marine Sciences and Technologies where epizootic mortality have been occurred during the larval and post-larval stage.

Generally, molluscan larvae are susceptible to bacterial pathogens, especially during their temporary fixation on the bottom of the tank where they are exposed to high concentration of potential pathogenic bacte- ria associated with the tank surface, moribund larvae or organic detritus (Sutton and Garrick, 1993). Vibrio alginolyticus is considered to be a part of marine biota (Vandenberghe et al., 1998; Xie et al., 2005; Mechri et al., 2011). However some works have shown them as one of the most pathogenic bacteria for bivalve larval cultures (Luna-González et al., 2002; Anguiano et al., 1998).

The enterobacterial repetitive intergenic consensus (ERIC) sequences are present in many copies in the genomes of enterobacteria and Vibrionaceae bacteria (Versalovic et al., 1991; Hulton et al., 1991; Fabiano et al., 2004). The ERIC-PCR fingerprinting technique is usually used as genetic marker to characterize isolates within Vibrio species (Marshall et al., 1999; Ashraf et al., 2001; Ben Kahla-Nakbi et al., 2006).

$V$. alginolyticus has a high rate of recombination with the diverse, closely related marine bacterial strains (González-Escalona et al., 2006). In fact several studies have reported that V.alginolyticus represents an

* Corresponding author: B. Mechri, Laboratoire des Maladies Transmissibles et Substances Biologiquement Actives, Université de Monastir, Faculté de Pharmacie, rue Avicenne 5000 Monastir, Tunisie; phone: (216) 21577741/73466950; fax: (216) 73466754; e-mail: mechri_bader@yahoo.fr 
important recipient of some V.cholerae and V.parahaemolyticus virulence genes transfers (Sechi et al., 2000; Xie et al., 2005; Snoussi et al., 2008b; Ben Abdallah et al., 2009). The mobility of the virulence-factor genes and a successful transfer may cause the transformation of a nonpathogenic strain to a pathogenic one (Boyd et al., 2000; Hentschel et al., 2000; Faruque and Nair, 2002).

The purpose of this study was to determine the relationship between $54 \mathrm{~V}$. alginolyticus strains isolated from a Tunisian R. decussatus hatchery using ERIC-PCR fingerprinting technique and to investigate the presence of $10 \mathrm{~V}$. cholerea virulence-factor genes (toxRS, toxR, toxT, toxS, tcp $P, \operatorname{tcp} A$, ace, vpi, zot and $\operatorname{ct} x A)$ among these strains. In addition, we tested the antibacterial susceptibility, the enzymatic and the cytotoxic activities.

\section{Experimental}

\section{Material and Metods}

Bacterial strains. A total of $54 \mathrm{~V}$. alginolyticus isolates collected from a Tunisian $R$. decussatus hatchery were analyzed in this study, including 14 strains from post-larva and rearing tanks, 12 from larva and rearing tanks, 10 from broodstock and breeder tanks, 10 were isolated from sea water inside the hatchery, 5 from larva food and 3 from broodstock food. All the V. alginolyticus isolates were screened by colony color on thiosulfate citrate bile salt sucrose (TCBS) medium (supplemented with $2 \% \mathrm{NaCl}$ ) and were further identified by the biochemical tests as described by Mechri et al. (2011).

Antibacterial susceptibility. Bacterial susceptibility to antimicrobial agents was performed by disc diffusion method on Mueller Hinton agar plates (bioMérieux, France) supplemented with $1 \% \mathrm{NaCl}$ as described by Ottaviani et al. (2001). A total of 20 antibiotics were used on the basis of previous reports (Ottaviani et al., 2001; Ben Kahla et al., 2006; Snoussi et al., 2008a). These antibiotics are: ampicillin $(10 \mu \mathrm{g})$, chloramphenicol $(30 \mu \mathrm{g})$, co-trimoxazole $(25 \mu \mathrm{g})$, ciprofloxacin $(5 \mu \mathrm{g})$, gentamicin $(10 \mu \mathrm{g})$, flumequine $(30 \mu \mathrm{g})$, nalidixic acid $(30 \mu \mathrm{g})$, streptomycin $(10 \mu \mathrm{g})$, tetracyclin $(30 \mu \mathrm{g})$ erythromycin $(15 \mu \mathrm{g})$, polymyxin B (300 units), cephalothin $(30 \mu \mathrm{g})$, , imipenem $(10 \mu \mathrm{g})$, doxycyclin (30 units), kanamycin $(30 \mu \mathrm{g})$, carbenicillin $(100 \mu \mathrm{g})$, norfloxacin $(5 \mu \mathrm{g})$, nitrofurantoin $(300 \mu \mathrm{g})$, oxolonic acid $(10 \mu \mathrm{g})$, colistinsulphate $(25 \mu \mathrm{g})$. After incubation at $37^{\circ} \mathrm{C}$ for $18-24 \mathrm{~h}$, the diameters of the inhibition zone were interpreted according to the "Comité de la Société Française de l'Antibiogramme" (Cavallo et al., 2006) and following by the recommendations of the National Committee for Clinical Laboratory Standards (NCCLS, 2002), the strains were categorized as susceptible or resistant to the drug. Escherichia coli ATCC 25922 was used as a control throughout all the experiments.
Minimum Inhibitory Concentration (MIC). The minimum inhibitory concentration of four antibiotics (ampicillin, erythromycin, tetracyclin and streptomycin) was determined using the broth microdilution method in Muller Hinton broth (bioMérieux, France) supplemented with $2 \% \mathrm{NaCl}(\mathrm{pH} 7,2)$ as described by the Clinical and Laboratory Standards Institute recommendations (M7-A7; CLSI, 2006). Vibrio strains were streaked on Trypticase Soy Agar plates (TSA) supplemented with $2 \% \mathrm{NaCl}$ and incubated at $30^{\circ} \mathrm{C}$ for $24-48 \mathrm{~h}$. Single colonies were suspended in $0.85 \%$ saline and the turbidity was compared with the 0.5 McFarland standard, to produce a bacterial suspension of $10^{8} \mathrm{CFU} / \mathrm{ml}$. Last inoculums concentration of $10^{5} \mathrm{CFU} / \mathrm{ml}$ was obtained in sterile $U$ shaped bottom 96-well microtiter plates containing the test concentrations of antibiotics $(0.125-256 \mathrm{mg} / \mathrm{l})$ and incubated at $35^{\circ} \mathrm{C}$ for 18-20 h. Escherichia coli ATCC 25922 was used as a control microorganism.

ECPs preparation and enzymatic profile. The extracellular products (ECPs) were obtained by the cellophane plate technique (Liu, 1957; Amaro et al., 1992) by spreading $1 \mathrm{ml}$ of an overnight culture of the isolated strains over sterilized cellophane sheets placed on TSA plates supplemented with $1 \% \mathrm{NaCl}$. After incubation for $24 \mathrm{~h}$ at $25^{\circ} \mathrm{C}$, bacterial cells were washed off the cellophane sheets with phosphate-buffered saline (PBS - 1\% $\mathrm{NaCl}),(\mathrm{pH} 7.0)$. The respective suspensions were centrifuged at $12000 \mathrm{~g}$ for $30 \mathrm{~min}$ at $4^{\circ} \mathrm{C}$. The supernatants obtained were sterilized by means of a $0.45 \mu \mathrm{m}$ pore size nitrocellulose filters (Millipore, Germany). ECP samples were stored at $-20^{\circ} \mathrm{C}$ until used. The API ZYM system (bioMérieux, France) was used for characterization of the global enzymatic activities of the $V$. alginolyticus strains ECPs. Assays were performed according to the manufacturer's recommendations at $25^{\circ} \mathrm{C}$.

Genotypic confirmation. The biochemically typical isolates of $V$. alginolyticus were subjected to PCR for further confirmation of their identity. DNA was extracted from the bacterial strains using Wizard genomic DNA purification kit (Promega, France) according to the manufacturer's instructions. In this study we targeted a $d n a J$ sequence, a housekeeping gene that encodes heat shock protein 40, VM-F (5'-CAGGTTTGYTGCACGGCGAAGA-3') and V.al2-MmR (5'-GATCGAAGTRCCRACACTMGGA-3'). These primers amplify a $144 \mathrm{bp}$ long fragment (Nhung et al., 2007). Amplification reactions contained 5x PCR buffer (Promega, France), $200 \mu \mathrm{mol} / 1$ of each desoxyribonucleotide triphosphate, $1.5 \mathrm{mmol} / \mathrm{l}$ of $\mathrm{MgCl}_{2}, 1 \mathrm{U}$ Taq polymerase (Promega, France), $1 \mu \mathrm{mol} / \mathrm{l}$ of each primer, and $2 \mu \mathrm{l}$ of the template in a final reaction volume of $25 \mu \mathrm{l}$. PCR amplifications were carried out in a thermal cycler (Eppendorf, Mastercycler personal) as follows: 3-min initial denaturation step, followed by 35 cycles 
of $94^{\circ} \mathrm{C}$ for $30 \mathrm{~s}, 60^{\circ} \mathrm{C}$ for $30 \mathrm{~s}$, and $72^{\circ} \mathrm{C}$ for $1 \mathrm{~min}$, with a final extension step of $7 \mathrm{~min}$ at $72^{\circ} \mathrm{C}$.

ERIC PCR. PCR was performed with the following primer sequences ERIC 1 (5'-ATGTAAGCTCCTGGGGATTCAC-3') and the reverse primer ERIC 2 (5'AAGTAAGTGACTGGGGTGAGCG) (Versalovic et al., 1991). Reactions were performed in a $50 \mu \mathrm{l}$ volume in an Eppendorf, Mastercycler personal thermocycler. Amplification reactions contained 5x PCR buffer (Promega, France), $200 \mu \mathrm{mol} / \mathrm{l}$ of each desoxyribonucleotide triphosphate, $1.5 \mathrm{mmol} / \mathrm{l}$ of $\mathrm{MgCl}_{2}, 1 \mathrm{U}$ Taq polymerase (Promega, France), $1 \mu \mathrm{mol} / \mathrm{l}$ of each primer, and $2 \mu \mathrm{l}$ of the template. Amplifications were made with 1 cycle at $95^{\circ} \mathrm{C}$ for $5 \mathrm{~min}, 30$ cycles at $90^{\circ} \mathrm{C}$ for $30 \mathrm{~s}, 52^{\circ} \mathrm{C}$ for $30 \mathrm{~s}$, $70^{\circ} \mathrm{C}$ for $1 \mathrm{~min}$, and $1 \mathrm{cycle}$ at $70^{\circ} \mathrm{C}$ for $10 \mathrm{~min}$. PCR products were visualized under UV-light after electrophoresis on a $1.2 \%$ agarose gel by ethidium bromide staining and photographed using Gel Doc XR apparatus (Biorad, Milan). The DNA fingerprints obtained were evaluated for similarity using both Gel Pro Analyser 4.0 software and by visual inspection of band patterns. Dendrogram was constructed by the unweighed pair group method of arithmetic averages (UPGMA) and Jaccard's correlation coefficient using the MVSP 3.2 software (Snoussi et al., 2008a).

Virulence genes. The oligonucleotide primers positions and sources for each of the selected virulenceassociated factors were listed in table I. All the PCR reactions were performed in a $50 \mu \mathrm{l}$ volume with $10 \mu \mathrm{l}$ of 5x PCR reaction buffer (Promega, France), $200 \mu \mathrm{mol} / \mathrm{l}$ of each of the four dNTPs, $1.5 \mathrm{mmol} / 1 \mathrm{MgCl}_{2}$ (Promega, France), $1 \mu \mathrm{mol} / \mathrm{l}$ of each primer, $1 \mu \mathrm{l}$ extracted DNA, 1.25 U Taq polymerase (Promega, France) and sterile ultrapure water. The mixtures were incubated for $5 \mathrm{~min}$ at $94^{\circ} \mathrm{C}$, followed by 35 cycles of amplification. Apart from the primer annealing temperature, each cycle consisted of denaturation at $94^{\circ} \mathrm{C}$ for $40 \mathrm{sec}$, annealing for $40 \mathrm{sec}$, and primer extension at $72^{\circ} \mathrm{C}$ for $1 \mathrm{~min}$ then the mixtures were kept at $72^{\circ} \mathrm{C}$ for $10 \mathrm{~min}$. The annealing temperature was $54^{\circ} \mathrm{C}$ for toxRS, toxR and toxT, $58^{\circ} \mathrm{C}$ was used for $t c p P, t c p A$, toxS and ace whereas the temperature was $60^{\circ} \mathrm{C}$ for $v p i$, zot and ctxA. The amplification products were separated by agarose gel electrophoresis (1.6\%), visualized following ethidium bromide staining, and photographed under UV-light using Gel Doc XR apparatus (Bio-Rad, Milan).

In vitro cytotoxicity assay. HeLa (human cervical epitheloid carcinoma) cells were grown in MEM (Minimum Essential Medium, Sigma) supplemented with $10 \%$ of foetal calf serum (Sigma), $1 \%$ of antibiotic solution (Streptomycin-Penicillin 5000 U, Sigma), and $1 \%$ of non-essential aminoacids (Sigma). Cells were seeded on 24 -well tissue culture plates $\left(2 \times 10^{4} \mathrm{cell} / \mathrm{ml}\right)$, and incubated at $37^{\circ} \mathrm{C}$ in $5 \% \mathrm{CO}_{2}$ for $24 \mathrm{~h}$. Vibrio strains were grown on TCBS agar (Scharlau Microbiogy, Spain), at $37^{\circ} \mathrm{C}$ for $18-24$ h. V. alginolyticus isolates were drawn and inoculated in TSB (Bio-Rad, France) supplemented with $1 \%$ of $\mathrm{NaCl}$, and incubated at $37^{\circ} \mathrm{C}$ for $18-24 \mathrm{~h}$. At the end of incubation, the flask contents were transferred to sterile $50 \mathrm{ml}$ test tubes and

Table I

PCR primers used in this study

\begin{tabular}{|c|c|c|c|}
\hline Target genes & PCR primer sequences $\left(5^{\prime}-3^{\prime}\right)$ & Product size (bp) & Reference \\
\hline tox RS & $\begin{array}{l}\text { toxR0, ATGAGTCATATTGGTACTTAAATT } \\
\text { toxS2, AACAGTACCGTAGAACCGTGA }\end{array}$ & 1397 & Sechi et al. (2000) \\
\hline tox $\mathrm{T}$ & $\begin{array}{l}\text { toxT1, TTGCTTGGTTAGTTATGAGAT } \\
\text { toxT2, TTGCAAACCCAGACTGATAT }\end{array}$ & 581 & Sechi et al. (2000) \\
\hline tox $\mathrm{R}$ & $\begin{array}{l}\text { toxR1, CCT TCG ATC CCC TAA GCA ATA C } \\
\text { toxR2, AGG GTT AGC AAC GAT GCG TAA G }\end{array}$ & 779 & Rivera et al. (2001) \\
\hline toxS & $\begin{array}{l}\text { toxS1, CCACTGGCGGACAAAATAACC } \\
\text { toxS2, AACAGTACCGTAGAACCGTGA }\end{array}$ & 640 & Sechi et al. (2000) \\
\hline$z o t$ & $\begin{array}{l}\text { zot1, ACGTCTCAGACATCAGTATCGAGTT } \\
\text { zot2, ATTTGGTCGCAGAGGATAGGCCT }\end{array}$ & 198 & Colombo et al. (1994) \\
\hline ace & $\begin{array}{l}\text { ace1, GCTTATGATGGACACCCTTTA } \\
\text { ace2, TTTGCCCTGCGAGCGTTAAAC }\end{array}$ & 284 & Colombo et al. (1994) \\
\hline$t c p \mathrm{P}$ & $\begin{array}{l}\text { tcpP1, CGAATGCAGTAATCAAGTCT } \\
\text { tcpP2, CAGTCAGCTTCATCAACAAT }\end{array}$ & 320 & Sechi et al. (2000) \\
\hline$t c p \mathrm{~A}$ & $\begin{array}{l}\text { tcpA1, CACGATAAGAAAACCGGTCAAGAG } \\
\text { tсpA2, ACCAAATGCAACGCCGAATGGAGC }\end{array}$ & 617 & Keasler and Hall (1993) \\
\hline$v p i$ & $\begin{array}{l}\text { VPI1, GCAATTTAGGGGCGCGACGT } \\
\text { VPI2, CCGCTCTTTCTTGATCTGGTAG }\end{array}$ & 680 & Sechi et al. (2000) \\
\hline $\operatorname{ctx} \mathrm{A}$ & $\begin{array}{l}\text { ctx2, CGGGCAGATTCTAGACCTCCTG } \\
\text { ctx3, CGATGATCTTGGAGCATTCCCAC }\end{array}$ & 563 & Field et al. (1992) \\
\hline
\end{tabular}


centrifuged at $3000 \mathrm{rpm}$ for $15 \mathrm{~min}$. The supernatant was filtered through a 0.45 and $0.22 \mu \mathrm{m}$ pore size filter membrane (Millipore, Germany). The bacterial filtrates (diluted 1:10, 1:50, 1:100), were added to HeLa cell monolayers, previously washed in PBS, and incubated at $37^{\circ} \mathrm{C}$ in $5 \% \mathrm{CO} 2$ for $24 \mathrm{~h}$ (Baffone et al., 2005). At the end of incubation, cells were observed for the presence of cytotoxic effect (rounding to $\geq 50 \%$ of cells). All assays were repeated three times and the readings were averaged. The filtrates showing cytotoxic effect at a 1:10 dilution were considered to be weak $(\mathrm{W})$ producers of toxin, those at a 1:50 dilution were moderate (M) producers, and those at a 1:100 dilution were strong $(\mathrm{S})$ producers (Barbieri et al., 1999).

Statistical analysis. All data were analyzed with SPSS for Windows, version 16.0. The relationship between isolates and virulence factors was studied by the Crosstabs methods. For all test $\mathrm{P}$-values $<0.05$ were considered significant.

\section{Results}

Biochemical, enzymatic and molecular characterization. The biochemical profiles obtained from the analysis of $54 \mathrm{~V}$.alginolyticus strains tested on API $20 \mathrm{E}$ miniaturized system showed heterogeneity of the bacterial population isolated from different compartments of the R. decussatus hatchery. In fact, among the studied strains we recognized 15 biotypes (Table II). All tested strains of $V$. alginolyticus were positive to indole test and most of them (48/54) were positive to lysine decarboxylase test while seven strains showed positive result to citrate test. All Vibrio strains were able to grow in nutrient broth prepared respectively with 2, 4, 6 and $8 \%$ of $\mathrm{NaCl}$ and produced acid from glucose and sucrose. Twenty three strains were amygdaline positive and only four strains were positive to sorbitol test. All strains tested amplified a $144 \mathrm{pb}$ size fragment corresponding to the heat shock protein 40 gene specific for this species (Fig. 1).

In the API ZYM system, complete homogeneity was observed among all the isolates for phosphatase alcaline, esterase Lipase (C8), leucine arylamidase, valine arylamidase, trypsin and acid phosphatase. However, over than $75 \%$ of the tested strains produced both esterase (C4) and Naphtol-AS-BI-phosphohydrolase. Enzymatic activity was also detected for $\alpha$-chymotrypsine (37\%), $\mathrm{N}$-acétyl- $\beta$-glycosaminidase (35\%), $\beta$-glucosidase (22\%), Lipase (C4) (9\%), $\alpha$-mannosidase (7\%) and $\beta$-glucoronidase (5\%).

Antibiotic susceptibility. According to the results, most of Vibrio isolates showed strong resistance to at least ten of the following antimicrobials: ampicillin (AM), kanamicin (K), nitrofurantoin (FT), doxycyclin

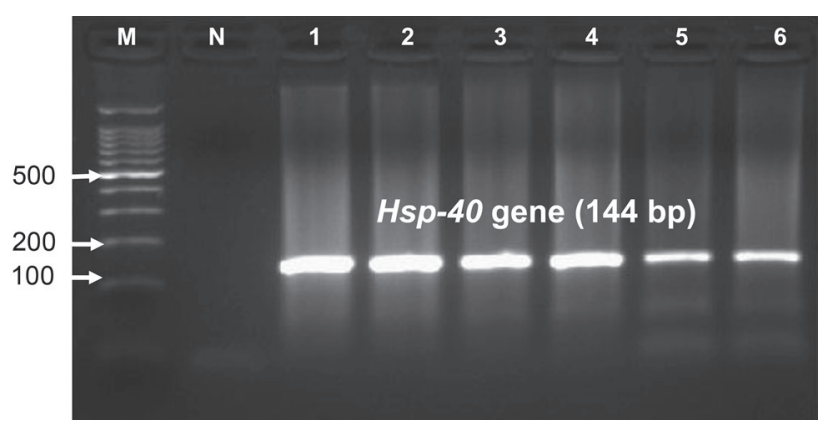

Fig. 1. Agarose gel electrophoresis (2\% agarose) of the amplification products obtained for heat shock protein 40 gene.

(M): molecular weight marker (100-pb DNA ladder, Promega); (N): negative control; lane (1 to 5): V. alginolyticus (strains: $\mathrm{L}_{12}, \mathrm{PL}_{48}, \mathrm{~B}_{5}$, $\left.\mathrm{W}_{9}, \mathrm{LF}_{4}\right) ;$ Lane (6): V. alginolyticus ATCC 33787

(DO), carbenicillin (CB), norfloxacin (NOR), erythromycin (E), streptomycin (S), gentamicin (GM), tetracyclin (T) and oxolinic Acid (OA) (Fig. 2). The highest rates of resistance were against $\mathrm{AM}, \mathrm{K}$ and $\mathrm{FT}(100 \%)$, followed by E (96.3\%), CB and DO (94.4\%), NOR (90.7\%), S (88.8\%), GEM (81.5\%), T (75.9\%), and OA (70.4\%). Sixty one percent of the tested strains were resistant to imipenem (IMP), 51.8\% to chloramphenicol (C) and 35.2\% to co-trimoxazol (STX). The lowest percentages of resistance were observed with nalidixic acid (NA, 16.6\%), colistin-sulphate (CT, 9.2\%), ciprofloxacin (CIP, 5.5\%), cephalotin (CF, 3.7\%), polymyxin B (PMB, $1.8 \%$ ) and flumequin (UB, $1.8 \%$ ).

The values of the MIC's of ampicillin, erythromycin, tetracyclin and streptomycin against 54 strains of $V$. alginolyticus recovered from $R$. decussatus hatchery are presented in table II. The data showed that tetracyclin $(0.5-64 \mathrm{mg} / \mathrm{l})$ and streptomycin $(1-64 \mathrm{mg} / \mathrm{l})$ were the most effective antimicrobials against the tested isolates. While most of these strains exhibit a strong resistance to ampicillin (4-256 mg/l) and erythromycin $(0.5-256 \mathrm{mg} / \mathrm{l})$. The minimum inhibitory concentration values corresponded to the interpretive MIC breakpoints for susceptibility among V. cholerae (CLSI 2006).

ERIC-PCR. The results for ERIC-PCR in this study showed a high diversity of polymorphism among $V$. alginolyticus strains isolated from different compartments of $R$. decussatus hatchery. Vibrio strains showed reproducible patterns consisting of 2 to 14 bands over a size range of $0.15 \mathrm{~kb}-10 \mathrm{~kb}$ estimated using the Gel Pro Analyser 4.0 software. ERIC PCR fingerprinting revealed 39 genetic patterns (Fig. 3), V.alginolyticus strains isolated from sea water inside the hatchery (40 to 49 ) had the highest genotypic diversity with nine different patterns followed by post-larva strains (1 to 14), larva strains (15 to 26) and broodstock strains (27 to 36 ) with eight patterns. Four genotypes were identified from larva food (50 to 54) and three from broodstock food (37 to 39). These results were analyzed using the MVSP 3.2 software to construct the 


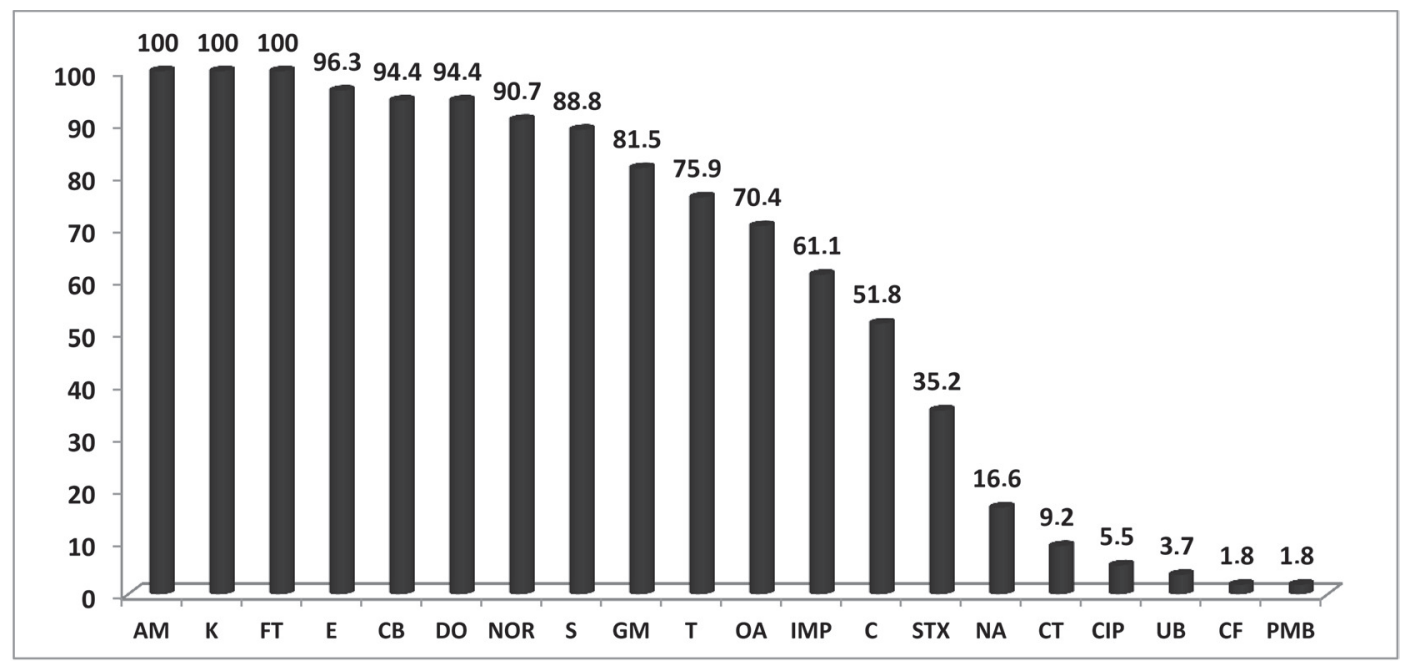

Fig. 2. Antibiotic resistance patterns of selected V. alginolyticus isolates expressed in \%.

AM - ampicillin, K - kanamycin, FT - nitrofurantoin, E - erythromycin, CB - carbenicillin, DO - doxycyclin, NOR - norfloxacin, S - streptomycin, GM - gentamicin, T - tetracyclin, OA - oxolonic acid, IMP - imipenem, C - chloramphenicol, STX - co-trimoxazol, NA - nalidixic acid, CT - colistin-sulphate, CIP - ciprofloxacin, UB - flumequin, CF - cefalotin, PMB - polymyxin B.
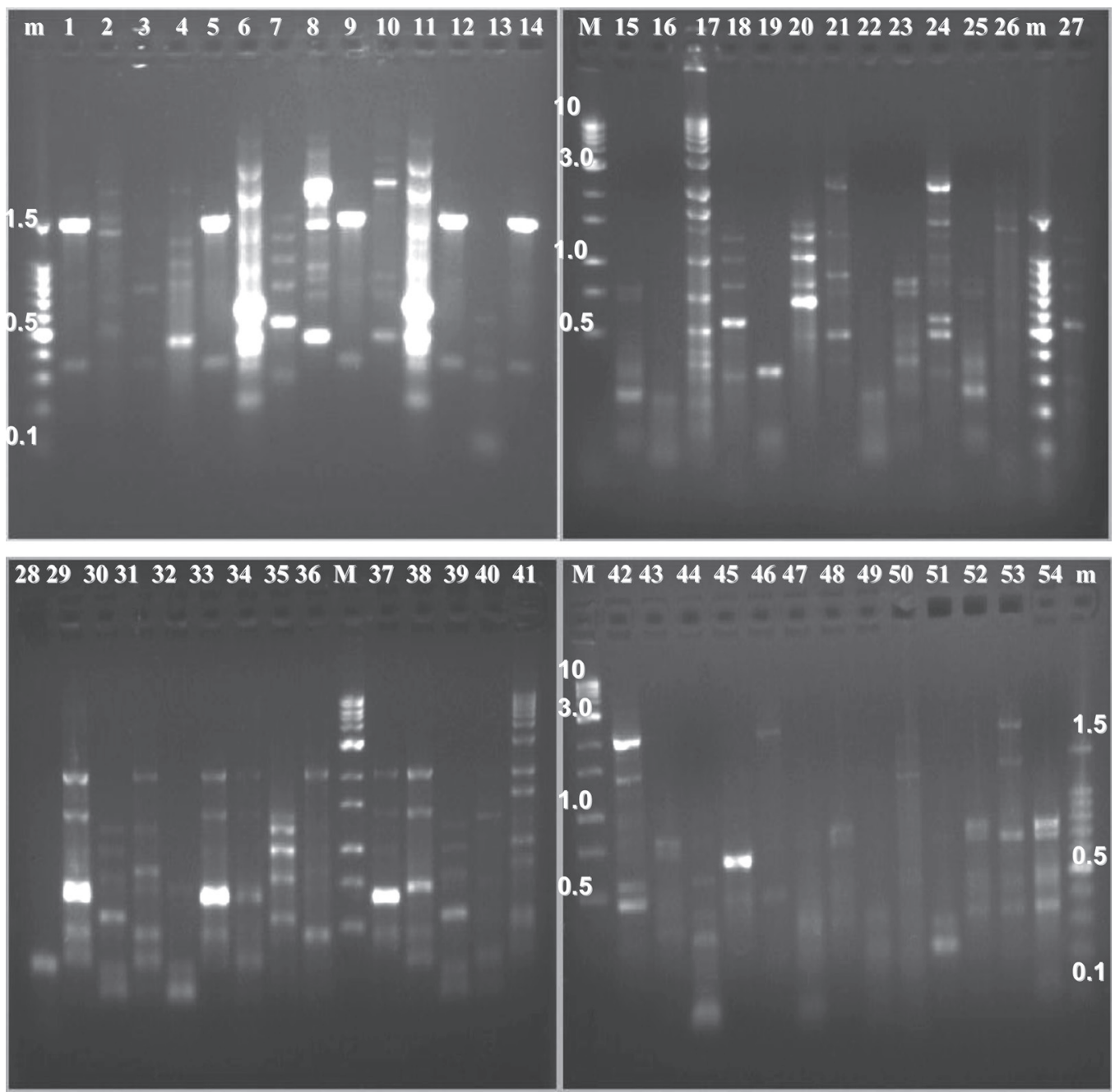

Fig. 3. Fingerprint patterns for the ERIC PCR of V. alginolyticus isolates run on $1.5 \%$ agarose gel.

Lanes: $\mathrm{m}$ - molecular weight (Promega, $100 \mathrm{pb}$ ), M - molecular weight (Biolabs, $1 \mathrm{~kb}$ ); 1 to 14, post-larva samples ( $\mathrm{PL}_{1} 15, \mathrm{PLW}_{1}$ 19, $\mathrm{PL}_{1} 22$, $\mathrm{PL}_{1} 27$, $\mathrm{PL}_{1}$ 39, PL 1 18, $\mathrm{PL}_{2}$ 24, PLW $32, \mathrm{PL}_{2} 48, \mathrm{PL}_{3}$ 25, PLW $\left.32, \mathrm{PL}_{4} 34, \mathrm{PLW}_{4} 54, \mathrm{PL}_{5} 24\right) ; 15$ to 26, larva samples $\left(\mathrm{L}_{1} 2, \mathrm{~L}_{1} 6, \mathrm{LW}_{1} 6, \mathrm{~L}_{2} 4, \mathrm{LW}_{2} 8, \mathrm{~L}_{3} 6, \mathrm{~L}_{3} 12, \mathrm{~L}_{4}\right.$ 2, $\mathrm{L}_{4} 8$, $\left.\mathrm{LW}_{4} 12, \mathrm{~L}_{5} 4, \mathrm{~L}_{5} 10\right) ; 27$ to 36 , Broodstock $\left(\mathrm{B}_{1} 1, \mathrm{~B}_{1} 3, \mathrm{~B}_{2} 6, \mathrm{BW}_{2} 4, \mathrm{~B}_{2} 4, \mathrm{~B}_{3} 2, \mathrm{~B}_{3} 4, \mathrm{BW}_{3} 2, \mathrm{~B}_{4} 1, \mathrm{~B}_{5} 2\right) ; 37$ to 39 , Broodstock food $\left(\mathrm{BF}_{2} 6, \mathrm{BF}_{4} 3, \mathrm{BF}_{2} 4\right) ; 40$ to 49 ,

Water inside the hatchery (W4, W9, W17, W2 8, W33, W35, W46, W52, W58, W66); 50 to 54, Larva food $\left(\mathrm{LF}_{2} 6, \mathrm{LF}_{3} 4, \mathrm{LF}_{3} 8, \mathrm{LF}_{4} 2, \mathrm{LF}_{5} 4\right)$. 
Table II

Biotypes, MIC patterns, virulence genes and cytotoxic effects of Vibrio alginolyticus isolates

\begin{tabular}{|c|c|c|c|c|c|c|c|c|c|c|}
\hline \multirow{2}{*}{ Origins } & \multirow{2}{*}{ Strains } & \multirow{2}{*}{ Biotypes } & \multicolumn{4}{|c|}{ MIC (mg/l) } & \multicolumn{3}{|c|}{ Virulence genes } & \multirow{2}{*}{ Cytotoxicity } \\
\hline & & & $\mathrm{E}$ & $\mathrm{S}$ & $\mathrm{T}$ & $\mathrm{AM}$ & tox $R$ & toxT & toxs & \\
\hline \multirow{14}{*}{$\begin{array}{l}\text { Post-larva } \\
(\mathrm{n}=14)\end{array}$} & $\mathrm{PL}_{1} 15$ & 4045124 & 64 & 32 & 0.5 & 128 & - & + & - & - \\
\hline & $\mathrm{PLW}_{1} 19$ & 4046124 & 32 & 16 & 4 & 32 & + & - & + & - \\
\hline & $\mathrm{PL}_{1} 22$ & 4144125 & 128 & 64 & 32 & 128 & + & - & + & - \\
\hline & $\mathrm{PL}_{1} 27$ & 4146125 & 16 & 4 & 8 & 64 & + & - & + & - \\
\hline & $\mathrm{PL}_{1} 39$ & 4366124 & 8 & 4 & 16 & 16 & - & + & - & + \\
\hline & $\mathrm{PL}_{2} 18$ & 4366124 & 32 & 8 & 0.5 & 128 & + & + & + & ++ \\
\hline & $\mathrm{PL}_{2} 24$ & 4746524 & 32 & 32 & 2 & 64 & + & - & + & + \\
\hline & $\mathrm{PLW}_{2} 32$ & 4144124 & 8 & 64 & 16 & 256 & + & + & + & + \\
\hline & $\mathrm{PL}_{2} 48$ & 4045125 & 32 & 8 & 0.5 & 8 & + & + & + & ++ \\
\hline & $\mathrm{PL}_{3} 25$ & 0146124 & 0.5 & 4 & 8 & 64 & + & + & + & +++ \\
\hline & $\mathrm{PLW}_{3} 32$ & 4146124 & 4 & 2 & 16 & 128 & + & - & + & - \\
\hline & $\mathrm{PL}_{4} 34$ & 4046124 & 64 & 16 & 4 & 64 & + & + & + & ++ \\
\hline & $\mathrm{PLW}_{4} 54$ & 4146125 & 0.5 & 1 & 0.5 & 16 & - & - & - & - \\
\hline & $\mathrm{PL}_{5} 24$ & 4146124 & 128 & 4 & 8 & 64 & + & - & + & - \\
\hline \multirow{12}{*}{$\begin{array}{l}\text { Larva } \\
(\mathrm{n}=12)\end{array}$} & $\mathrm{L}_{1} 2$ & 4146125 & 4 & 8 & 0.5 & 8 & + & - & - & - \\
\hline & $\mathrm{L}_{1} 6$ & 4045125 & 256 & 16 & 8 & 256 & + & - & + & + \\
\hline & $\mathrm{LW}_{1} 6$ & 4045125 & 0.5 & 1 & 16 & 64 & + & - & - & - \\
\hline & $\mathrm{L}_{2} 4$ & 4146125 & 16 & 2 & 8 & 16 & + & + & + & ++ \\
\hline & $\mathrm{LW}_{2} 8$ & 4046124 & 32 & 64 & 32 & 16 & + & + & + & + \\
\hline & $\mathrm{L}_{3} 6$ & 4046125 & 128 & 1 & 0.5 & 32 & + & + & + & ++ \\
\hline & $\mathrm{L}_{3} 12$ & 0146124 & 32 & 4 & 4 & 128 & + & - & + & + \\
\hline & $\mathrm{L}_{4} 2$ & 4064125 & 64 & 4 & 16 & 8 & + & - & - & - \\
\hline & $\mathrm{L}_{4} 8$ & 4046024 & 8 & 16 & 2 & 4 & + & - & - & - \\
\hline & $\mathrm{LW}_{4} 12$ & 4746524 & 8 & 64 & 0.5 & 32 & + & + & + & ++ \\
\hline & $\mathrm{L}_{5} 4$ & 4247124 & 64 & 8 & 1 & 64 & + & + & + & ++ \\
\hline & $\mathrm{L}_{5} 10$ & 4247124 & 64 & 4 & 4 & 256 & + & + & + & ++ \\
\hline \multirow{10}{*}{$\begin{array}{l}\text { Broodstock } \\
(\mathrm{n}=10)\end{array}$} & $\mathrm{B}_{1} 1$ & 4044124 & 2 & 2 & 8 & 4 & + & - & + & - \\
\hline & $\mathrm{B}_{1} 3$ & 4064125 & 128 & 16 & 2 & 32 & + & - & - & - \\
\hline & $\mathrm{B}_{2} 6$ & 4064125 & 4 & 8 & 1 & 8 & + & + & + & +++ \\
\hline & $\mathrm{BW}_{2} 4$ & 0146124 & 32 & 32 & 16 & 128 & - & - & + & + \\
\hline & $\mathrm{B}_{2} 4$ & 4044125 & 8 & 8 & 0.5 & 4 & + & + & + & + \\
\hline & $\mathrm{B}_{3} 2$ & 4046124 & 64 & 1 & 8 & 128 & + & - & + & + \\
\hline & $\mathrm{B}_{3} 4$ & 0046124 & 32 & 16 & 4 & 16 & + & - & + & - \\
\hline & $\mathrm{BW}_{3} 2$ & 4046024 & 32 & 4 & 32 & 64 & + & - & + & - \\
\hline & $\mathrm{B}_{4} 1$ & 4044125 & 4 & 16 & 0.5 & 8 & - & + & + & + \\
\hline & $\mathrm{B}_{5} 2$ & 4146124 & 32 & 2 & 8 & 128 & + & + & + & + \\
\hline \multirow{10}{*}{$\begin{array}{l}\text { Seawater } \\
(\mathrm{n}=10)\end{array}$} & W4 & 4045124 & 32 & 32 & 64 & 32 & + & - & + & - \\
\hline & W9 & 4045125 & 2 & 4 & 16 & 16 & + & - & + & - \\
\hline & W17 & 4064125 & 64 & 16 & 2 & 128 & + & - & + & - \\
\hline & W28 & 0146124 & 16 & 4 & 4 & 64 & + & - & + & - \\
\hline & W33 & 4044525 & 32 & 8 & 0.5 & 16 & + & - & + & - \\
\hline & W35 & 4046124 & 32 & 4 & 4 & 64 & + & + & + & + \\
\hline & W46 & 4046124 & 128 & 1 & 1 & 128 & + & - & + & + \\
\hline & W52 & 4064125 & 128 & 4 & 0.5 & 32 & + & - & + & + \\
\hline & W58 & 4147124 & 32 & 1 & 2 & 256 & + & + & + & ++ \\
\hline & W66 & 4146125 & 256 & 2 & 0.5 & 64 & + & - & + & - \\
\hline
\end{tabular}


Table II continued

\begin{tabular}{|c|c|c|c|c|c|c|c|c|c|c|}
\hline \multirow{2}{*}{ Origins } & \multirow{2}{*}{ Strains } & \multirow{2}{*}{ Biotypes } & \multicolumn{4}{|c|}{ MIC (mg/l) } & \multicolumn{3}{|c|}{ Virulence genes } & \multirow{2}{*}{ Cytotoxicity } \\
\hline & & & $\mathrm{E}$ & $S$ & $\mathrm{~T}$ & $\mathrm{AM}$ & toxR & toxT & toxs & \\
\hline \multirow{5}{*}{$\begin{array}{l}\text { Larva food } \\
(\mathrm{n}=5)\end{array}$} & $\mathrm{LF}_{2} 6$ & 4144124 & 16 & 8 & 8 & 4 & + & - & + & - \\
\hline & $\mathrm{LF}_{3} 4$ & 4046124 & 0.5 & 8 & 8 & 16 & + & - & + & - \\
\hline & $\mathrm{LF}_{3} 8$ & 4044525 & 32 & 2 & 0.5 & 64 & + & + & + & + \\
\hline & $\mathrm{LF}_{4} 2$ & 4146125 & 4 & 4 & 32 & 8 & + & - & - & - \\
\hline & $\mathrm{LF}_{5} 4$ & 4044125 & 16 & 16 & 0.5 & 32 & + & - & + & + \\
\hline \multirow{3}{*}{$\begin{array}{l}\text { Breeder food } \\
(\mathrm{n}=3)\end{array}$} & $\mathrm{BF}_{2} 6$ & 0146124 & 8 & 8 & 0.5 & 16 & + & - & + & - \\
\hline & $\mathrm{BF}_{2} 4$ & 4346125 & 2 & 1 & 4 & 32 & + & - & + & - \\
\hline & $\mathrm{BF}_{4} 3$ & 4045124 & 16 & 4 & 4 & 64 & + & - & + & + \\
\hline
\end{tabular}

Antibiotics: AM - ampicillin, E - erythromycin, CB - carbenicillin, S - streptomycin, T - tetracyclin.

Cytotoxicity: - none, + weak, ++ moderate, +++ strong.

phylogenetic dendrogram and to be able to estimate the relationship between isolates. Some strains isolated from the same source but from different ponds were classified into one genotype type. In fact, the
V.alginolyticus strains $\mathrm{PL}_{1} 15$ and $\mathrm{PL}_{1} 39$ (lanes 1 and 5) were isolated from post-larva samples in the first pond, while strain $\mathrm{PL}_{2} 48$ (lane 9) was recovered from the second pond, the isolate $\mathrm{PL}_{4} 34$ (lane 12) from the

\section{UPGMA}

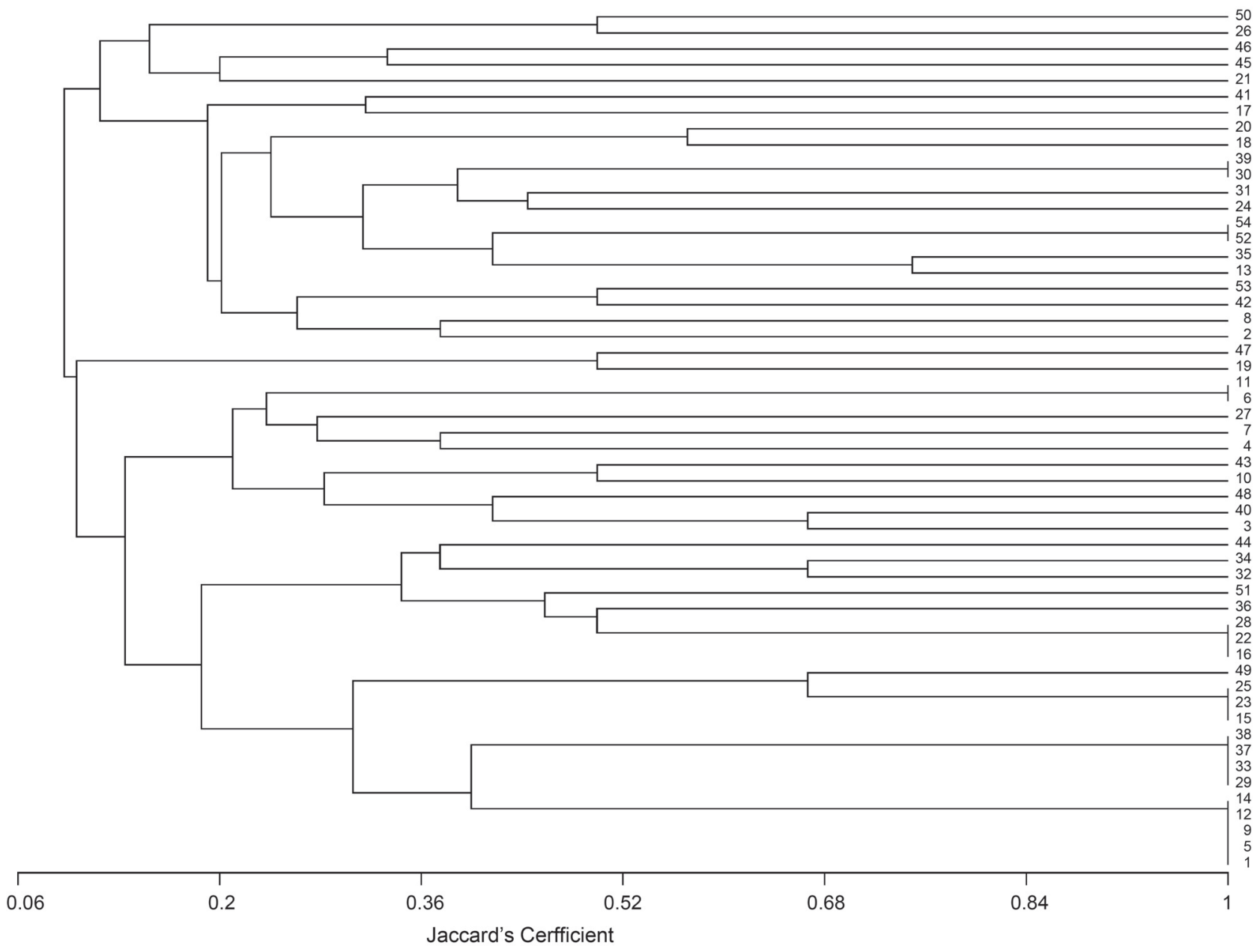

Fig. 4. Dendrogram showing genetic relationships between V. alginolyticus isolates based on ERIC-PCR fingerprints.

V. alginolyticus strains: 1 to 14, post-larva samples ( $\mathrm{PL}_{1} 15, \mathrm{PLW}_{1} 19, \mathrm{PL}_{1} 22, \mathrm{PL}_{1}$ 27, $\mathrm{PL}_{1} 39, \mathrm{PL}_{2} 18, \mathrm{PL}_{2} 24$, $\mathrm{PLW}_{2} 32, \mathrm{PL}_{2} 48, \mathrm{PL}_{3} 25, \mathrm{PLW}_{3} 32, \mathrm{PL}_{4} 34$, $\mathrm{PLW}_{4}$ 54, $\left.\mathrm{PL}_{5} 24\right) ; 15$ to 26, larva samples $\left(\mathrm{L}_{1} 2, \mathrm{~L}_{1} 6, \mathrm{LW}_{1} 6, \mathrm{~L}_{2} 4, \mathrm{LW}_{2} 8, \mathrm{~L}_{3} 6, \mathrm{~L}_{3} 12, \mathrm{~L}_{4} 2, \mathrm{~L}_{4} 8, \mathrm{LW}_{4} 12, \mathrm{~L}_{5} 4, \mathrm{~L}_{5} 10\right) ; 27$ to 36, Broodstock $\left(\mathrm{B}_{1} 1, \mathrm{~B}_{1} 3, \mathrm{~B}_{2} 6, \mathrm{BW}_{2} 4\right.$, $\left.\mathrm{B}_{2} 4, \mathrm{~B}_{3} 2, \mathrm{~B}_{3} 4, \mathrm{BW}_{3} 2, \mathrm{~B}_{4} 1, \mathrm{~B}_{5} 2\right) ; 37$ to 39 , Broodstock food $\left(\mathrm{BF}_{2} 6, \mathrm{BF}_{2} 4, \mathrm{BF}_{4} 3\right) ; 40$ to 49 , Water inside the hatchery (W4, W9, W17, W28, W33, W35, W46, W52, W58, W66); 50 to 54, Larva food $\left(\mathrm{LF}_{2} 6, \mathrm{LF}_{3} 4, \mathrm{LF}_{3} 8, \mathrm{LF}_{4} 2, \mathrm{LF}_{5} 4\right)$. 


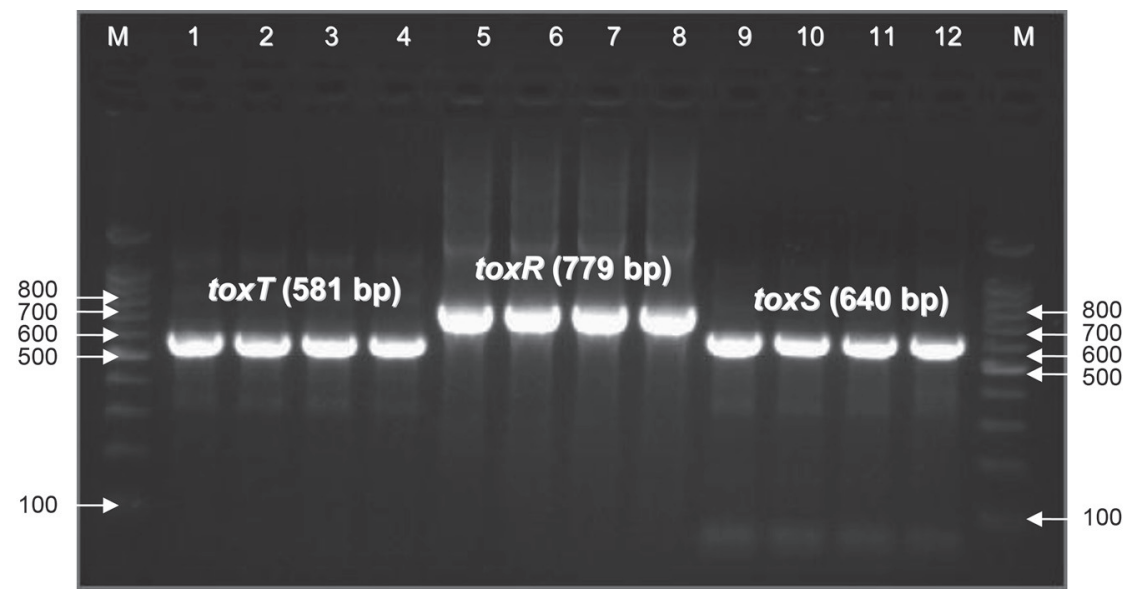

Fig. 5. Agarose gel electrophoresis (1.6\% agarose) of the toxT (lanes 1 to 4 ); toxR (lanes 5 to 8 ) and toxS (lanes 9 to 12) amplification products of different Vibrio alginolyticus isolates.

M: molecular weight marker 100 bp ladder (Pro mega, France); 1, $\mathrm{PL}_{2} 48 ; 2, \mathrm{~L}_{2} 4 ; 3, \mathrm{~B}_{2} 6 ; 4, \mathrm{~W} 35 ; 5, \mathrm{PL}_{4} 34 ; 6, \mathrm{~L}_{3} 6 ; 7, \mathrm{~B}_{3} 2$; 8 , W9; 9, $\mathrm{PL}_{2} 48 ; 10, \mathrm{~L}_{3} 6 ; 11, \mathrm{~W} 58 ; 12, \mathrm{LF}_{3} 8$.

fourth pond and $\mathrm{PL}_{5} 24$ (lane 14) from the fifth pond. The strain $\mathrm{PL}_{2} 18$ (lane 6) was isolated from the second pond and $\mathrm{PLW}_{3} 32$ (lane 11) from the third pond. The Vibrio strains $\mathrm{L}_{1} 2, \mathrm{~L}_{4} 8$ and $\mathrm{L}_{5} 4$ (lanes 15, 23 and 25) were recovered from larva samples (ponds 1, 4 and 5) presented the same genotype profile, whereas strains $\mathrm{L}_{1} 6$ (lane 16, pond 1) and $\mathrm{L}_{4} 2$ (lane 22, pond 4) showed identical patterns, indicating a high degree of similarity. Bacterial strains $\mathrm{LF}_{3} 8$ (lane 52, pond 3) and $\mathrm{LF}_{5} 4$ (lane 54, pond 5) were isolated from larva food samples belonged to the same genotype group (Fig. 4). However, other isolates collected from different origins showed an identical pattern, indicating that they belonged to the same clone (Fig. 4). The V. alginolyticus isolates $\mathrm{B}_{2} 6$ (lane 29, pond 2) and $\mathrm{BW}_{2} 4$ (lane 30, pond 2) recovered from broodstock and breeder tanks water samples presented the same genotype profile with $\mathrm{BF}_{2} 6$ (lane 37 , pond 2) and $\mathrm{BF}_{2} 4$ (lane 39 , pond 2) strains isolated from broodstock food samples (Fig. 4).

Virulence genes and cytotoxic activity. The results obtained in the PCR experiments of the Vibrio cholerae virulence genes demonstrated that 49/54 strains showed positive results in the amplification of the toxS gene. Additionally, the toxR fragment was amplified from the chromosome of $45 / 54 \mathrm{~V}$. alginolyticus strains whereas the toxT gene was found in 22/54 strains (Fig. 5). The crosstabs method revealed a significant relationship $(P=0.003)$ between the presence of the toxR gene and the toxS gene. All isolates gave negative results for the amplification of toxRS, tcpP, tcpA, vpi, zot and ctxA (Table II).

A cytotoxic activity against human HeLa cell line was observed with different degrees in $51.85 \%$ of the assayed strains. Only two isolates (3.7\%) gave a strong cytotoxic effect, nine (16.66\%) strains were moderately cytotoxic and 17 of $54(31.41 \%)$ strains were weakly cytotoxic (Table II).

\section{Discussion}

V. alginolyticus has often been isolated from molluscan hatcheries and has been considered to be responsible for epidemic mortalities in larval stages. As far as we know, this is the first time that this Vibrio species is isolated from a R. decussatus hatchery in the southern part of the Mediterranean. Yet, several studies conducted in Tunisia reported that V.alginolyticus causes damages and important economic loss in fish farms.

The phenotypic characterization of V.alginolyticus strains isolated from different compartments of $R$. decussatus hatchery showed that all isolates gives yellow colonies on TCBS agar and were able to grow in high salinity concentration. The biochemical characteristics of Vibrio strains were in accordance with those described previously by Ottaviani et al., (2003). However, these findings are in disagreement with Ben Kahla-Nakbi et al. (2007) who showed that a majority of $V$. alginolyticus strains isolated from dead and moribund fish samples were negative to indole test. V. alginolyticus strains were genetically identified to the species level using the Hsp-40 gene as described previously by Nhung et al. (2007).

Several studies showed that the API ZYM system provides a simple method for the discrimination of related Vibrio species (Biosca and Amaro, 1996; Balebona et al., 1998; Ben Kahla-Nakbi etal., 2007). In fact, the enzyme activity profiles of V.alginolyticus strains ECPs obtained corroborate previous studies showing approximately the same enzymatic activities (GómezLeón et al., 2005). On other hand, all the isolates examined gave positive results in tests for lipase, gelatinase and DNase. These data corroborated with the works of Mechri et al. (2011) and Snoussi et al. (2008a).

Epidemiological surveillance of antimicrobial resistance is essential for empirical treatment of infections 
and for preventing the spread of antimicrobial resistant bacterial infections (Adeyemi et al., 2008). The results from this study showed alarming resistance frequencies in $V$. alginolyticus strains isolated from $R$. decussatus hatchery to many antibacterial agents commonly used in aquaculture. V.alginolyticus has been reported in previous studies to be resistant to ampicillin, kanamycin, erythromycin, carbenicilin and nitrofurantoin (Lee et al., 1996; Hörmansdorfer et al., 2000 and Ottaviani et al., 2001). In this study, 45/54 (83\%) Vibrio isolates were resistant to at least 10 antibiotics; these results are in agreement with Snoussi et al. (2008a) and Mechri et al. (2011), who showed a huge resistance to the same antimicrobial agents.

In previous works, the ERIC-PCR fingerprinting technique was used to study the genetic distribution of V.alginolyticus strains isolated from Tunisian fish hatcheries. In fact, Ben Kahla-Nakbi et al. (2006) and Snoussi et al., (2008a) reported that the ERIC2-PCR is a very efficient tool for the molecular typing of V.alginolyticus species. In this study, of all 54 isolates typed by ERIC-PCR, we recognized 21 strains generating seven profiles. Interestingly, seven $V$. alginolyticus isolates $\left(\mathrm{PL}_{1} 15, \mathrm{PL}_{1} 39, \mathrm{PL}_{2} 48, \mathrm{PL}_{4} 34, \mathrm{PL}_{5} 24, \mathrm{PL}_{2} 18\right.$ and $\mathrm{PLW}_{3} 32$ ) recovered from different post-larva and tanks water samples belonged to two ERIC types. While two genotype profiles were found in clones originated from five Vibrio strains $\left(\mathrm{L}_{1} 2, \mathrm{~L}_{4} 8, \mathrm{~L}_{5} 4, \mathrm{~L}_{1} 6\right.$ and $\left.\mathrm{L}_{4} 2\right)$ isolated from different larva samples. Two isolates $\left(\mathrm{LF}_{3} 8\right.$ and $\mathrm{LF}_{5} 4$ ) from different larva food samples showed identical pattern. Moreover, three Vibrio strains $\left(\mathrm{L}_{1} 6, \mathrm{~L}_{4} 2\right.$ and $\mathrm{B}_{1} 3$ ) isolated respectively from Larva and broodstock samples belonged to the same genotype group. While five V. alginolyticus strains $\left(\mathrm{B}_{2} 6, \mathrm{~B}_{3} 4, \mathrm{BW}_{2} 4, \mathrm{BF}_{2} 6\right.$ and $\left.\mathrm{BF}_{2} 4\right)$ recovered respectively from broodstock and broodstock food samples belonged to two genotype profiles. These data confirmed that some Vibrio strains, isolated from the same or different ponds, were able to colonize different compartments of the $R$. decussatus hatchery.

Several studies have demonstrated that V.alginolyticus has the particularity to acquire virulence genes from other Vibrio species. Indeed, Sechi et al., (2000) have reported for the first time the dissemination of some V. cholerae virulence genes among related Vibrio species. Since there, Deriu et al. (2002); Xie et al. (2005) and Ben Kahla-Nakbi et al. (2009), reported the presence of DNA originating from V. cholerae and V.parahaemolyticus species in other Vibrio bacteria isolated from different marine ecosystems. Our findings corroborate with these results as the virulence gene toxR, tox $T$ and toxS have been detected in most of V.alginolyticus isolates. However, this is the first report of the high frequencies of dissemination of the tox $T$ gene (41\%) among V.alginolyticus species.
The cytotoxic effects of extracellular products of $V$.alginolyticus species has been reported against CHSE-214, EPC, FHM cells (Balebona et al., 1998) and HeLa cell lines (Baffone et al., 2005). These authors have suggested that the presence of cytotoxic activities in cell lines can be related to the virulence of V. alginolyticus strains. Results of this study showed that $51.85 \%$ of the analyzed strains present a cytotoxic effect against the tested cell line.

In conclusion, the study of $V$. alginolyticus genotypes from different structures of $R$. decussatus hatchery is useful to determinate the relatedness of Vibrio isolates and to elucidate the source of the bacterial contamination. Besides, this work highlights the incidence of multiple antibiotic resistance in V.alginolyticus strains and the large diffusion of some $V$. cholerae virulence genes among the studied strains. Pronounced cytotoxicity was also exhibited by the tested Vibrio isolates on HeLa cells.

\section{Literature}

Adeyemi A., V. Enyinnia, R. Nwanze, S. Smith and E. Omonigbehin. 2008. Antimicrobial susceptibilty of potentially pathogenic halophilic Vibrio species isolated from seafoods in Lagos. Nigeria. Afr. J. Biotech. 7: 3791-3794

Amaro C., E.G. Biosca, C. Esteve, B. Fouz and A.E. Toranzo. 1992. Comparative study of phenotypic and virulence properties in Vibrio vulnificus biotypes 1 and 2 obtained from a European eel farm experiencing mortalities. Dis. Aquat. Org. 13: 29-35.

Anguiano B.C., B.R. Searcy and P.M.L. Lizárraga. 1998. Pathogenic effects of Vibrio alginolyticus on larvae and post-larvae of the red abalone Haliotis rufescens. Dis Aquat. Org. 33: 119-122.

Ashraf A.K., S. McCarthy, R.F. Wang and C.E. Cerniglia. 2001. Characterization of United States outbreak isolates of Vibrio parahaemolyticus using enteriobacterial repetitive intergenic consensus ERIC PCR and development of a rapid PCR method for detection of O3, K6 isolates. FEMS. Microbiol. Lett. 206: 209-214.

Baffone W., E. Vittoria, R. Campana, B. Citterio, A. Casaroli and L. Pierfelice. 2005. Occurrence and expression of virulence related properties by environmental Vibrio spp. in vitro and in vivo systems. Food. Control. 16: 451-457.

Balebona MC., MJ. Andreu, MA. Bordas, I. Zorrilla, MA. Morinigo and JJ. Borrego. 1998. Pathogenicity of Vibrio alginolyticus for cultured gilt-head sea bream (Sparus aurata L.). Appl. Environ. Microbiol. 64: 4269-4275.

Barbieri, E., L. Falzano, C. Fiorentini, A. Pianetti, W. Baffone, A. Fabbri, P. Matarrese, A. Casiere, M. Katouli, I. Kuhn, R. Mollby, F. Bruscolini and G. Donelli. 1999. Occurrence, diversity, and pathogenicity of halophilic Vibrio spp. and non-O1 Vibrio cholerae from estuarine waters along the Italian adriatic coast. App. Envir. Microbio. 65: 2748-2753.

Ben Abdallah F., K. Chaieb, T. Zmantar, H. Kallel and A. Bakhrouf. 2009. Adherence assays and slime production of Vibrio alginolyticus and Vibrio parahaemolyticus. Braz. J. Microbiol. 40: 394-398.

Ben Kahla-Nakbi A., K. Chaieb and A. Bakhrouf. 2009. Investigation of several virulence properties among Vibrio alginolyticus strains isolated from diseased cultured fish in Tunisia. Dis. Aquat. Org. 86: 21-28.

Ben Kahla-Nakbi A., K. Chaieb, A. Besbes, T. Zmantar and A. Bakhrouf. 2006. Virulence and enterobacterial repetitive inter- 
genic consensus PCR of Vibrio alginolyticus strains isolated from Tunisian cultured gilthead sea bream and sea bass outbreaks. Vet. Microbiol. 117: 321-327.

Ben Kahla-Nakbi A., A. Besbes, K. Chaieb, M. Rouabhiab and A. Bakhrouf. 2007. Survival of Vibrio alginolyticus in seawater and retention of virulence of its starved cells. Mar. Environ. Res. 46: 469-478.

Biosca E.G. and C. Amaro. 1996. Toxic and enzymatic activities of Vibrio vulnificus biotype 2 with respect to host specificity. Appl. Environ. Microbiol. 62: 2331-2337.

Boyd E.F., K.E. Moyer, L. Shi and M.K. Waldor. 2000. Infections CТХ $\Phi$ and the Vibrio pathogenicity island prophage in Vibrio mimicus. Evidence for recent horizontal transfer between V. mimicus and V. cholerae. Infect. Immun. 68: 1507-1513.

Cavallo J.D., H. Chardon, C. Chidiac, P. Choutet, P. Courvalin, H. Dabernat, H. Drugeon, L. Dubreuil, F. Goldstein, V. Jarlier, R. Leclerc, M.H. Nicolas-Chanoine, A. Philippon, C. Quentin, B. Rouveix, J. Sirot and C.J. Soussy. 2006. Comité de l’antibiogramme de la société Française de Microbiologie Communiqué 2006.

Clinical and Laboratory Standards Institute. 2006. Wayne, PA: Clinical and Laboratory Standards Institute, Methods for dilution antimicrobial susceptibility tests for bacteria that grow aerobically. M7-A7. 26: 14-16.

Colombo M.M., S. Mastrandea, A. Santona, A.P. De Amdrade, S. Uzzau, S. Rubino and P. Cappuccinelli. 1994. Distribution of the ace, zot and ctxA toxin genes in clinical and environmental Vibrio cholerae. J. Fish. Dis. 170: 750-751.

Deriu A., L.A. Sechi, P. Molicotti, M.L. Spanu and S. Zanetti. 2002. Virulence genes in halophilic Vibrio spp. isolated in common mussels. Microbiologica 25: 93-96.

Fabiano L.T., T. Iida and J. Swings. 2004. Biodiversity of Vibrios. Microbiol. Mol. Biol. Rev. 68 (3): 403-431.

Faruque S.M. and G.B. Nair. 2002. Molecular ecology of toxigenic Vibrio cholerae. Microbiol. Immunol. 46: 59-66.

Fields P.I., T. Popovic, K. Wachsmuth and O. Olsvik. 1992. Use of polymerase chain reaction for detection of toxigenic Vibrio cholerae O1 strains from the Latin American cholera epidemic, J. Clin. Microbiol. 30: 2118-2121.

Gonzalez-Escalona N., GM. Blackstone and A. DePaola. 2006. Characterization of a Vibrio alginolyticus strain isolated from Alaskan oysters carrying a hemolysin gene similar to the thermostable direct hemolysin-related hemolysin gene trh of Vibrio parahaemolyticus. Appl. Environ. Microbiol. 72: 7925-7929.

Gomez-Leon J., L. Villamil, ML. Lemos, B. Novoa and A. Figueras. 2005. Isolation of Vibrio alginolyticus and Vibrio splendidus from aquacultured carpet shell clam (Ruditapes decussatus) larva associated with mass mortalities. Appl. Environ. Microbiol. 71(1): 98-104. Hamida L., M.N. Medhioub, J.C. Cochard, M.S. Romdhane and M. Le Pennec. 2004. Etude comparative du cycle de reproduction de la palourde Ruditapes decussatus en milieu naturel sud Tunisie et contrôlé écloserie. Cah. Biol. Mar. 45: 291-303.

Hentschel U., M. Stelnert and J. Hacker. 2000. Common molecular mechanisms of symbiosis and pathogenesis. Trends. Microbiol. 8: 226-231.

Hörmansdorfer S., H. Wentges, K. Neugebaur-Büchler and J. Bauer. 2000. Isolation of Vibrio alginolyticus fromseawater aquaria. Int. J. Hyg. Environ. Health. 203: 169-175.

Hulton C.S.J., C.F. Higgins and P.M. Sharp. 1991. ERIC sequences, a novel family of repetitive elements in the genomes of Escherichia coli, Salmonella typhimurium and other enterobacteria. Molecular. Microbiology 5: 825-834.

Keasler S.P. and R.H. Hall. 1993. Detecting and biotyping Vibrio cholerae $\mathrm{O} 1$ with multiplex polymerase chain reaction. Lancet 341 : 1661.
Lee K.K., S.R. Yu, F.R. Chen, T.I. Yang and P.C. Liu. 1996. Virulence of Vibrio alginolyticus isolated from diseased tiger prawn Penaeus monodon. Curr. Microbiol. 32: 229-231.

Liu P.V. 1957. Survey of hemolysin production among species of pseudomonads. J. Bacteriol. 74 : 718-727.

Lubert P.E. 1984. Biologie de la reproduction des mollusques bivalves d'importance commerciale en Méditerranée. Haliotis. 14: 49-68.

Luna-González A., A.N. Maeda-Martínez, J.C. Sainz and F. Ascencio-Valle. 2002 Comparative susceptibility of veliger larvae of four bivalve mollusks to a Vibrio alginolyticus strain. Dis. Aquat. Org. 49: 221-226.

Marshall S., C.G. Clark, G. Wang, M. Mulvey, M.T. Kelly and W.M. Johnson. 1999. Comparison of molecular methods for typing Vibrio parahemolyticus. J. Clin. Microbiol. 37: 2473-2478.

Mechri B., A. Medhioub, M.N. Medhioub and M. Aouni. 2011. Diversity of Vibrionaceae associated with Ruditapes decussatus hatchery in Tunisia. Ann. Microbiol. 61: 597-606.

Medhioub M.N. 1983. La conchyliculture en Tunisie. Projet Tunis/92/002. Direction Générale de la Pêche et de l'Aquaculture. PNUD/FAO. pp. 83.

National Committee for Clinical Laboratory Standards. 2002. Performance standards for antimicrobial disk and dilution susceptibility tests for bacteria isolated from animals. Tentative standards. Document M31-T. NCCLS., Wayne.

Nhung P.H., M.M. Shah, K. Ohkusu, M. Noda, H. Hata, X.S. Sun, H. Iihara, K. Goto, T. Masaki, J. Miyasaka and T. Ezaki. 2007. DnaJ gene as a novel phylogenetic marker for identification of Vibrio species. J. Syst. Appl. Microbiol. 30: 309-315.

Ottaviani D., I. Bacchiocchi, L. Masini, F. Leoni, A. Carraturo, M. Giammarioli and G. Sbaraglia. 2001. Antimicrobial susceptibility of potentially pathogenic halophilic vibrios isolated from seafood. Int. J. Antimicrob. Agents. 18: 135-140.

Parache A. 1982. La palourde. La Pêche Maritime. 1254: 496-507. Rivera I.N.G., J. Chun, A. Huq, R.B. Sack and R.R. Colwell. 2001. Genotypes associated with virulence in environmental isolates of Vibrio cholera. Appl. Environ. Microbiol. 67: 2421-2429.

Sechi L.A., I. Dupre, A. Deriu, G. Fadda and S. Zanetti. 2000. Distribution of Vibrio cholerae virulence genes among different Vibrio species isolated in Sardinia., Italy. J. Appl. Microbiol. 88: 475-481.

Snoussi M., H. Hajlaoui, E. Noumi, S. Zanetti and A. Bakhrouf. 2008a. Phenotypic and molecular characterization of Vibrio alginolyticus strains recovered from juveniles and older Sparus aurata reared in a Tunisian marine farm. Ann. Microbiol. 58 (1): 141-146. Snoussi M., E. Noumi, D. Usai, L.A. Sechi, S. Zanetti and A. Bakhrouf. 2008b. Distribution of some virulence related-properties of Vibrio alginolyticus strains isolated from Mediterranean seawater Bay of Khenis., Tunisia, investigation of eight Vibrio cholerae virulence genes. World. J. Microbiol. Biotechnol. 24: 2133-2141. Sutton D.C. and R. Garrik. 1993. Bacterial disease of cultured giant clam Tridacna gigas larvae. Dis. Aquat. Org. 16: 4753.

Vandenberghe J., Y. Li, L. Verdonck, J. Li, P. Sorgeloos, H.S. Xu and J. Swings. 1998. vibrios associated with Penaeus chinensis Crustacea, Decapoda larvae in Chinese shrimp hatcheries. Aquaculture 169: $121-132$

Versalovic J., T. Koueth and J.R. Lupski. 1991. Distribution of repetitive DNA sequences in eubacteria and application to fingerprinting of bacterial genomes. Nucleic. Acid. Research. 19: 6823-6831.

Xie Z.Y., C.Q. Hu, C. Chen, L.P. Zhang and C.H. Ren. 2005. Investigation of seven Vibrio virulence genes among Vibrio alginolyticus and Vibrio parahaemolyticus strains from the coastal mariculture systems in Guangdong., China. Lett. App. Microbiol. 41: 202-207. 